\author{
Agnieszka Judkowiak \\ Koszalin University of Technology \\ e-mail: agnieszka.judkowiak@tu.koszalin.pl \\ ORCID: 0000-0002-5220-1993
}

\title{
THE IDENTIFICATION OF PROBLEMS RELATED TO ELECTRONIC FINANCIAL STATEMENTS - OWN RESEARCH RESULTS
}

\section{IDENTYFIKACJA PROBLEMÓW ZWIĄZANYCH Z ELEKTRONICZNYMI SPRAWOZDANIAMI FINANSOWYMI - WYNIKI BADAŃ WLASNYCH}

DOI: $10.15611 /$ pn.2019.6.03

JEL Classification: M41

Summary: E-financial statements constitute a new dimension of financial reporting in Poland. They were introduced in response to the ongoing digitization of the economy. These changes resulted in a number of problems for the accountants, which the legislator did not foresee. The purpose of the work was to identify problems arising during the preparation, signing and submission of e-financial statements. The research material was collected using the direct survey method. The research tool was a survey questionnaire. The respondents were people who prepared at least one e-financial statement for 2018. The conducted research shows that most of the identified problems are the consequence of the too rapid introduction of the new regulations without introducing a transitional period for the whole of the new requirements.

Keywords: financial reporting, e-financial statements, accounting act, electronic signature, ePUAP.

Streszczenie: E-sprawozdania stanowią nowy wymiar sprawozdawczości finansowej w Polsce. Zostały one wprowadzone w odpowiedzi na postępujący proces cyfryzacji gospodarki. Zmiany te spowodowały pojawienie się wielu problemów z punktu widzenia księgowych, których ustawodawca nie przewidział. Celem pracy była identyfikacja problemów powstałych przy sporządzaniu, podpisywaniu i przekazywaniu e-sprawozdań. Materiał badawczy zebrano z zastosowaniem metody sondażu bezpośredniego. Narzędziem badawczym był kwestionariusz ankiety. Respondentami były osoby, które sporządziły przynajmniej jedno e-sprawozdanie za rok 2018. Z przeprowadzonych badań wynika, że większość ze zidentyfikowanych problemów jest konsekwencją zbyt szybkiego terminu wejścia w życie nowych regulacji bez wprowadzenia okresu przejściowego dla obowiązywania całości nowych wymogów.

Słowa kluczowe: sprawozdawczość finansowa, e-sprawozdanie finansowe, ustawa o rachunkowości, podpis elektroniczny, ePUAP. 


\section{Introduction}

A financial statement is a significant document for an enterprise. It is a source of information about the property and financial situation as well as the achieved results of a given business entity. In 2018 Poland introduced changes regarding the form in which the financial statements are to be prepared. The new requirements were published in several legal acts, including, the Act on the National Court Register (Act of 20 August 1997), the Accounting Act (Act of 29 September 1994), the Personal Income Tax Act (PIT Act) (Act of 26 July 1991), the Corporate Income Tax Act (CIT Act) (Act of 15 February 1992) and the Act on Expert auditors, audit firms and public oversight - Act on Statutory Auditors (Act of 11 May 2017). The changes introduced are a consequence of the implementation of the Directive on certain aspects of company law (Directive (EU) 2017/1132 of the European Parliament and of the Council of 14 June 2017). The implementation of the directive's provisions into the national legal order of the Member States of the European Union is aimed, among others, at integrating commercial registers and companies in the European Union and the European Economic Area, which will reduce information asymmetry on the European market by providing all interested parties with faster and easier access to corporate information and documents.

The new legal regulations introduced Polish financial reporting into a new era. The e-statements have replaced the paper form. The new procedure for making financial statements available to the public is largely intended to simplify the acquisition of financial information about business entities for stakeholders. However, the preparation, signing and submission of e- financial statements for the first time contained some errors and mistakes, and turned out to be a great challenge for accountants.

The purpose of the work was to identify the problems arising during the preparation, signing and submission of e-financial statements. The study attempts to answer the questions of how did the change in balance sheet regulations affect the work of accountants, and what problems did the financial statement makers struggle with when fulfilling their new responsibilities?

Previous studies related to electronic financial statements focused on two aspects: online financial statements (in the form of scans or PDF files posted on the Internet) and the expanded language of financial reporting - XBRL.

The research in the field of online financial statements conducted so far concerned, among others: comparing the scope of online financial reporting among companies from different countries (Debreceny, Gray, and Rahman, 2002), the development of internet reporting over the years with particular emphasis on published financial statements (Davis, Clements, and Keuer, 2003), analysis of information disclosed in online financial statements over the years along with an assessment of their usefulness for the investors (Marston and Polei, 2004), identification of the factors contributing to increasing the willingness of the companies to disseminate financial information and other corporate information on the Internet (Xiao, Yang, and Chow, 2004), verifying 
company websites in terms of providing online access to financial statements (Momany and Al-Shorman, 2006), assessing the content, availability and ease of use of online financial statements compared to their paper counterpart (Levtzion-Korach, Alcalai, Orav, Graydon-Baker, Keohane, Bates, and Frankel, 2009), identifying the main benefits of online financial statements (Khan, Ismail, and Zakuan, 2013).

The second area of research related to the issue of electronic financial statements is the concept of XBRL (eXtensible business reporting language). XBRL is a financial reporting language based on XML meta-language. This is a new language of financial reporting adopted worldwide (Manmohan and Mishra, 2014). XBRL allows creating, exchange and analyzing information contained in financial statements, and also facilitates the exchange and reliable transfer of data between various applications via the Internet. The multithreading of the extended language of financial reporting gives many opportunities to conduct research in this area. The main research perspectives in the field of XBRL include research on the idea of the XBRL standard (Wu and Vasarhelyi, 2004), analysis of benefits and problems associated with its application, and an assessment of the future use of this standard as a tool supporting financial reporting (Pinsker and Li, 2008; Klimczak, 2014; Manmohan and Mishra, 2014; Klimczak, 2019) and eliminating information asymmetry (Yoon, Zo, and Ciganek, 2011). The impact of using the extended language of financial reporting on the users of reports (Baldwin, Brown, and Trinkle, 2006) and channels ensuring the wider and more effective use of XBRL technology were also examined (Dunne, Helliar, Lymer, and Mousa, 2013).

The implementation of the obligation to prepare electronic financial statements in business practice provided the opportunity to conduct research on electronic reports taking into account the opinion of accountants regarding their preparation, signing and forwarding to the competent authorities. So far, little attention has been paid to this discourse, both in Poland and around the world. This is mainly due to the fact that this is a new problem for accountants. Therefore, it requires an analysis and indication of the errors that the legislator has not avoided. The indication of these errors may constitute the basis for improving the procedures related to the preparation, signing and submission of e-financial statements.

The conducted research is the first stage of research on issues related to e-reporting. In further studies it is planned to conduct surveys using a questionnaire in the bodies accepting electronic financial statements (National Court Register and tax offices) to identify the problems arising as a result of implementing the obligation to submit reports electronically. The conclusions obtained in the course of research may be useful in further work related to the "From paper to digital Poland" program implemented by the Ministries of Development, Digitization, Finance, Infrastructure and National Education.

\section{E-financial statements - new rules and obligations}

In 2018 a number of changes were introduced in the area of financial reporting. The first was the creation of a repository of financial documents (Act on the National Court Register, art. 9a), which should be submitted from 15 March 2018: annual 
financial statements; audit reports, if the financial statements were audited; a copy of the resolution approving the financial statements and distribution of profit or covering losses; and an activity report if the entity was required to prepare one (the Accounting Act, art. 69, paragraph 1). This means that from now on, financial statements must be submitted only electronically. Another important change is the obligation to provide the documents to the National Court Register with a qualified signature or a trusted signature. From 1 October 2018 another amendment entered into force, which obliged entities keeping accounting books in accordance with the Accounting Act to prepare financial statements in electronic form, maintaining the appropriate logical structure and format. From that moment, e-financial statements are the only form of providing information about the property and financial situation and the results of operations of an enterprise, permissible by the Accounting Act, applicable to all reports prepared after that date (Act of 29 September 1994, art. 45, paragraph 1f).

Such a sequence of introducing changes in practice meant that the period from 15 March 2018 to 30 September 2018 was a transitional period in which entities could still prepare a financial statement in a paper version, while submission to the National Court Register required electronic procedures, i.e. prepared and signed financial documents in paper form had to be scanned, creating an electronic copy in PDF format, which had to be electronically signed by at least one person authorized to submit financial documentation. From 1 October 2018 the obligations related to the electronic transmission and electronic signing of financial statements were joined by the obligation to maintain the electronic form of preparation of financial statements.

The reports on the activities of certain units also take an electronic form (Act of 29 September 1994, art. 49, paragraph 7) as well as separate and consolidated reports on payments to the administration (Act of 29 September 1994, art. 63k). The form of their preparation is an electronic file (text, graphic or mixed), which can be saved and read using a computer program. The types of allowed data formats are included in the Regulation on the National Interoperability Framework, minimum requirements for public registers and electronic exchange of information, as well as minimum requirements for ICT systems. The following formats should be mentioned: XAdES, PAdES, CAdES, XMLsig, xml, txt, rtf, pdf, xps, odt, ods, odp, doc, docx, xls, xlsx, csv, jpg, tif, gif (Regulation of the Council of Ministers of 12 April 2012, Annex 2).

More detailed format solutions are presented for the financial statements of two groups of entities:

- for entities entered in the register of entrepreneurs of the National Court Register $(\mathrm{KRS})^{1}$ keeping accounting books in accordance with Polish accounting

${ }^{1}$ Partnerships and capital companies, European economic interest groupings, European companies, cooperatives, European cooperatives, state-owned enterprises, mutual insurance and reinsurance companies, branches of foreign entrepreneurs operating in the territory of the Republic of Poland, main branches of foreign insurance and reinsurance companies, budgetary economy institutions, or other legal persons conducting economic activity who are subject to the obligation to enter into the register of associations, other social and professional organizations, foundations and public health care institutions (Act of 20 August 1997, art. 36). 
principles, the preparation of financial statements in a logical structure and XML format is required (Act of 29 September 1994, art. 45, paragraph 1g),

- for natural persons who are taxpayers of income tax from natural persons keeping accounting books, the financial statements must be prepared in a logical structure and in XML format (Act of 26 July 1991, art. 45, paragraph 5).

The financial statements of other entities approve any accepted file format. The logical structures of e-financial statements are available on the website of the Ministry of Finance (Ministry of Finance - National Court Administration (MF-KAS), 2019). They are presented in XSD format, taking into account the division of units according to the annexes to the Accounting Act and the specific form of business operations for which specific accounting principles apply, which were established in the form of regulations as implementing acts to the Accounting Act. In addition, the structures take into account the level of rounding used in the unit when presenting value data.

According to the Accounting Act (Act of 29 September 1994, art. 52), the head of the entity is required to ensure that the annual financial statements are prepared within three months of the balance sheet date and presented to the competent authorities.

The prepared financial statements should be provided with a qualified electronic signature $^{2}$ or a signature confirmed by a trusted profile ${ }^{3}$ (Act of 29 September 1994, art. 45, paragraph 1f).

The financial statements are subject to approval within six months of the balance sheet date (Act of 29 September 1994, art. 53, paragraph 1). Before approving the financial statements, if there is such an obligation, or the entity has voluntarily decided, the annual financial statements should be audited by an auditor (Act of 29 September 1994, art. 53, paragraph 2). Amendments to the Act on the National Court Register also resulted in amendments to the Act on Statutory Auditors, Audit Firms and Public Oversight (Act of 11 May 2017). Article 86, paragraph 1 obliges experts to prepare an audit report in electronic form with a qualified signature of the statutory auditor. Such an obligation was imposed on statutory auditors in the event of auditing the financial statements of an enterprise entered in the Register of Entrepreneurs of the National Court Register. With reference to units not entered in the register of entrepreneurs of the National Court Register, the audit report may have a paper form with a traditional expert's signature.

There were also significant changes in the scope of submitting financial statements. The place of submitting financial statements depends on the type of business unit (MF Tax Portal, 2019):

${ }^{2}$ Qualified electronic signature means an advanced electronic signature which is created using a qualified electronic signature creation device and which is based on a qualified electronic signature certificate (Regulation (EU) No 910/2014 of the European Parliament and of the Council of 23 July 2014 (eIDAS ), art. 3, paragraph 12).

${ }^{3} \mathrm{~A}$ trusted profile is an alternative to a paid qualified signature. It is a free tool that allowsone to confirm one's identity on the Internet and place trusted signatures. 
- entrepreneurs entered in the National Court Register (KRS) - only to the National Court Register within 15 days of approval - if the entity accounts in accordance with the calendar year - by July 15 of the following year,

- entrepreneurs - PIT taxpayers - to the Head of the National Tax Administration (KAS) until April 30 of the following year,

- taxpayers of corporate income tax not entered in the register of entrepreneurs of the National Court Register - to the tax office to the electronic mailbox of the tax authority (ePUAP) or by delivering to the tax office on an electronic data carrier (10 days from approval).

It should be emphasized that the scope of additional annual documentation required when submitting the financial statements has not changed. It should also be noted that pursuant to art. $80 \mathrm{~b}$ of the Tax Criminal Code (Act of 10 September 1999), for failing to submit the financial report or audit report to the competent tax authority within the time limit, there is a fine for a tax offence. A fine or imprisonment of up to two years, or both, jointly, are also provided for in Accounting Act (Act of 29 September 1994, art. 77) for failure to prepare a financial statement or its preparation that does not comply with the provisions of the Accounting Act or the incorporation of unreliable data.

\section{Research methodology}

The direct survey method was used to achieve the goal. The research tool was a survey questionnaire. The survey questionnaire consisted of five open questions. The questions in the questionnaire referred to the following indications:

1. Did the changes in the legal regulations regarding financial reporting cause you difficulties in reporting?

2. Which stage of reporting was the most problematic for you?

3. What problems did you encounter while preparing the e-financial statement?

4. What problems arose when creating electronic signatures?

5. What difficulties did you encounter while submitting the financial statements to the appropriate body (KRS/KAS)?

Forty accountants from the Zachodniopomorskie [West Pomeranian] Voivodeship took part in the study. The respondents did not agree to disclose detailed data about the units in which they are employed. The prerequisites for conducting the research were:

- the preparation of at least one financial statement for 2018 by the respondent,

- at least one of the reports prepared concerned a unit entered in the register of entrepreneurs in the National Court Register or a natural person.

The imposition of such conditions indicates the experience acquired by the respondent at each stage of the reporting work carried out in accordance with the new regulations. 


\section{Results}

Studies have shown that there are many problems with electronic financial statements. All the respondents unanimously indicated that the implementation of the new requirements in the field of financial reporting significantly hindered and extended the reporting work, compared to previous years. To a large extent, the difficulties were caused by the non-adaptation of financial and accounting programs to the new requirements, waiting for their update and the extended waiting time for the help of programmers or IT specialists supporting financial and accounting programs. In the opinion of the respondents, a big problem was the too rapid implementation of new reporting obligations into practice, with no transitional period for all requirements, i.e. covering not only the signing and submission of financial statements, but also their preparation in the appropriate structure and format. Most of the respondents had problems at every stage of the reporting work, and were repeatedly solved by the 'trial and error method'.

Therefore the problems were divided into three areas corresponding directly to individual stages of reporting work. These are areas such as preparing, signing and forwarding e-financial statements to the relevant authorities.

The problems most frequently mentioned by accountants in the area of preparing e-financial statements include:

- determining whether an e-financial statements should be prepared in a logical structure and in XSD format for a given unit or in any permitted electronic format with an electronic signature, due to the dispersion of the obligation to maintain the appropriate form and format of the e-financial statements between the three acts (Accounting Act, PIT Act and CIT Act),

- illegibility of logical structures included on the pages of the Ministry of Finance presented in the XSD format for accountants, as they are a tool for programmers and IT specialists adjusting financial and accounting programs,

- too late extension of the application that facilitates the preparation and signing of financial statements by entities entered into the Register of Entrepreneurs of the National Court Register, initially the application enabled the preparation, signing and sending of e-financial statements only to natural persons keeping accounting books subject to PIT tax,

- incurring additional costs related to fulfilling new reporting obligations (purchase of a module, application, updating of the existing program enabling preparation, signing and sending of e-financial statements, training on new requirements related to e-financial statements),

- too long waiting period for the tools of the accounting service to fulfill reporting obligations (program updates, new modules and applications enabling the preparation of reports in the appropriate form and format), which significantly shortened the accounting period for preparing financial statements to as little as one month (the new tools were possible to purchase at the turn of January and 
February at the earliest, while the financial statements had to be prepared by the end of March), it should be emphasized that the biggest problem in this respect concerned accountants providing bookkeeping services who were required to prepare from several to even several dozen reports,

- too high costs of the programs, modules and applications used to fulfill the new obligations in relation to the frequency of using them (once a year),

- conclusion of contracts with clients by service accountants keeping books of accounts, before introducing changes to regulations, without being aware of the additional costs related to fulfilling new obligations related to e-financial statements,

- the need for software developers to correct software in connection with the problems arising during the preparation of financial statements (errors in file generation, attaching data from the existing finance and accounting program from the 2017 annual report to the 2018 e-financial statements in order to obtain comparable data, lack of compatibility of the current program with the purchased modules or applications of other companies, adding additional notes and explanations that do not have the indicated format), which definitely hindered, lengthened and prevented work on preparing the e-financial statements.

The surveys showed that significant problems concerned the signing of the

financial statements, in particular:

- the Accounting Act allows the choice of signature between a qualified electronic signature or a signature confirmed by an ePUAP trusted profile, while the eKRS system, through which the report should be sent, did not accept reports signed by ePUAP until the end of January, which was changed after the intervention of the accounting community, however many accountants decided to buy qualified signatures,

- incurring additional costs related to the acquisition of a qualified electronic signature,

- complex procedures for signing with the ePUAP trusted profile (sending the report to the ePUAP server, when signing the report by several people, each of them must have their own trusted profile and the person preparing a separate account to which he/she delegates access to all board members),

- it is not possible to sign the financial statements of entities that have not been obliged to maintain an appropriate logical structure and XSD format, a trusted profile, because its use changes the PDF file to an unreadable XML file,

- difficulties related to signing reports by foreigners,

- discrepancies in the interpretation of statutory auditors as to which signatures certify the date of preparation of the financial statements - some recognized the date of the first signature (as a rule, the person entrusted with keeping the books of account), regardless of when the head of the entity, or possibly all management board members will sign the report, others however, the experts pointed out that the date of preparation should be the date of the last signature of all those obliged to do so, 
- the need to maintain the correct order of signatures, if the persons obliged to sign the financial statements had different types of signatures, so some of the signatures were qualified and some were made by a trusted profile,

- auto corrections, corrections at the auditor's request in the period after the report was prepared and before its approval, required re-passing the same signing procedures as in the original version.

The last, but equally important stage of fulfilling the reporting obligations is submitting the financial statement to the appropriate body. In this area, accountants most often pointed out the following problems:

- changes in reporting procedures, which has caused uncertainty among all accountants of meeting all reporting obligations,

- at the stage of sending documents, accountants received notifications of errors related to the use of a qualified electronic signature, which resulted in starting the signing procedure from the beginning, the problem also concerned files attached to the financial statements, such as the auditor's report,

- during the sending of documents, accountants received information about the inconsistency of the XML file with the logical structure presented by the Ministry of Finance without additional explanations, which consequently constitutes a problem related to failure to fulfill reporting obligations, as the reports already approved are sent to the National Court Register and after that time it is not possible to make corrections in the financial statement,

- incurring additional costs regarding submitting the report to the National Court Register in the absence of the possibility of using the free system,

- technical problems - the eKRS system identifies a given unit by KRS number, entering the unit into the system using the NIP number was impossible, problems with attaching files submitted together with the report and their format.

\section{Conclusions}

Issues related to e-financial statements can be considered from the point of view of the applicable legal regulations and practical solutions. Polish legal regulations contain provisions obliging business entities keeping accounting books to prepare financial statements in electronic form. This is a new obligation with which accountants, in most cases, struggled for the first time when preparing financial statements for 2018 . Research shows that the effect of implementing e-financial statements into business practice was the emergence of numerous problems in the area of the preparation, signing and submission of financial statements. Most of the problems identified may be due to the deadline for the new regulations to enter into force too soon without a transition period for all the new requirements to apply. According to the author, the transitional period should have been extended until the end of June 2019. This would have applied to the voluntary choice of the method of preparing the financial statements between e-financial statements in the appropriate logical structure, 
provided with an electronic signature and a paper version in the form of a scan, while maintaining electronic sending of financial documentation in both variants. This would have eliminated many of the problems presented when switching only to the new rules for preparing, signing and sending e-financial statements.

During the transition period from 15 March 2018 to 30 September 2018, the e-financial statements were in the form of a scanned document saved as a PDF file. This period did not allow for showing the imperfections that appeared at the time when all the regulations came into force. It was only the inclusion, from 1 October 2018, of the obligation to prepare financial statements in the appropriate logical structure and format, bearing an electronic signature to the previously implemented procedures for electronic submission of financial documentation, which created problems at every stage of reporting work such as the use of bad logical structures - reports, the order of making electronic signatures, the need to identify a business entity with the KRS number and not the NIP number.

A longer transitional period would have given IT specialists more time to prepare new tools to fulfill their statutory obligations, while accountants would have been able to go through the entire procedure for preparing, signing and forwarding e-financial statements, without being responsible, because if the e-financial statements are not submitted in the appropriate structure and format, accountants can prepare a report in accordance with the regulations currently in force. According to the author, it is also worth clarifying the regulations in the Accounting Act regarding deadlines for placing electronic signatures, as it is the electronic signature that currently certifies the timeliness of preparing the financial statements.

\section{Bibliography}

Act of 11 May 2017 on Statutory Auditors, Audit Firms and Public Oversight, Journal of Laws 2019, item 1421.

Baldwin, A. A., Brown, C. E., and Trinkle, B. S. (2006), XBRL: An Impacts Framework and Research Challenge. Journal of Emerging Technologies in Accounting, 3(1), 97-116. Retrieved from https:// www.aaajournals.org/doi/10.2308/jeta.2006.3.1.97

Davis, C. E., Clements, C., and Keuer, W. P. (2003). Web-based reporting a vision for the future, Strategic Finance 85(3), 44-49. Retrieved from https:/go.gale.com/ps/anonymous?id=GALE\%7CA118951782\&sid=googleScholar\&v=2.1\&it=r\&linkaccess $=$ abs\&issn $=1524833 \mathrm{X} \& \mathrm{p}=\mathrm{AON}-$ $\mathrm{E} \& \mathrm{sw}=\mathrm{W}$

Debreceny, R., Grey, G. L., and Rahman, A. (2002). The determinants of Internet financial reporting, Journal of Accounting and Public Policy 21(4-5), 371-394. Retrieved from https:/www. sciencedirect.com/science/article/pii/S0278425402000674

Directive (EU) 2017/1132 of the European Parliament and of the Council of 14 June 2017 relating to certain aspects of company law, Official Journal of Laws 169, as amended.

Dunne, T., Helliar, C., Lymer, A., and Mousa, R. (2013). Stakeholder engagement in internet financial reporting: The diffusion of XBRL in the UK, The British Accounting Review, 45(3), 167-182. Retrieved from https://www.sciencedirect.com/science/article/abs/pii/S0890838913000528 
Grabiński, K. (2007). XBRL jako etap ewolucji sprawozdawczości finansowej. Zeszyty Naukowe Akademii Ekonomicznej w Krakowie, (750).

Khan, M. N. A. A., Ismail, N. A., and Zakuan, N. (2013). Benefits of internet financial reporting in a developing countries: Evidence from Malaysia, African Journal of Business Management, 7(9), 719-726. Retrieved from https://www.researchgate.net/publication/258884965_Benefits_of_ internet_financial_reporting_in_developing_countries_Evidence_from_Malaysia

Klimczak, K. (2014). Standard XBRL jako koncepcja wspomagająca raportowanie finansowe, Studia Prawno-Ekonomiczne, XCI/2, 175.

Klimczak, K. (2019). Korzyści wynikające z zastosowania XBRL na potrzeby raportowania na rynkach kapitałowych w świetle stanowisk nadzorców rynków oraz badań naukowych, Acta Universitatis Lodziensis. Folia Oeconomica, 1(340), 57-72.

Levtzion-Korach, O., Alcalai, H., Orav, E. J., Graydon-Baker, E., Keohane, C., Bates, D. W., and Frankel, A. S. (2009). Evaluation of the contributions of an electronic web-based reporting system: Enabling action. Journal of Patient Safety, 5( 1), 9-15. Retrieved from https://www.ncbi.nlm.nih. gov/pubmed/19920433

Manmohan, M., and Mishra, P. K. (2014). A Study on Cost-Benefit Analysis of XBRL Reporting on Financial Data Ecosystem, International Journal of Advances in Management, Economics and Entrepreneurship, 01(01), 1-5. Retrieved from http://www.ijamee.info/index.php/IJAMEE/article/ view/23

Marston, C., and Polei, A. (2004). Corporate reporting on the Internet by German companies, International Journal of Accounting Information Systems, 5(3), 285-311. Retrieved from https:// www.sciencedirect.com/science/article/pii/S1467089504000387

MF-KAS, 2019. Retrieved from https://www.gov.pl/web/kas/struktury-e-sprawozdan (16.04.2019).

MF Tax Portal, 2019. Retrieved from https:/www.podatki.gov.pl/e-sprawozdania-finansowe/pliki-dopobrania/ (23.06.2019)

Momany, M. T., and Al-Shorman, S. A. (2006). Web-Based Voluntary Financial Reporting of Jordanian Companies, International Review of Business Research Papers 2(2), 127-139. Retrieved from https://www.researchgate.net/publication/303166449_Web-based_voluntary_financial_ reporting of Jordanian companies

Pinsker, R., and Li, S. (2008). Costs and benefits of XBRL adoption: early evidence. Communications of the ACM, 51(3), 47-50. Retrieved from https://www.researchgate.net/publication/220425024

Li_S_Costs_and_benefits_of_XBRL_adoption_early_evidence_Commun_ACM_513_47-50

Regulation of the Council of Ministers of April 12, 2012 on the National Interoperability Framework, minimum requirements for public registers and exchange of information in electronic form, as well as minimum requirements for ICT systems., Annex 2.

Wu, J., and Vasarhelyi, M. (2004). A New Tool For Electronic Financial Reporting. In: W. Anandarajan, A. Anandarajan, and C. A. Srinivasan, Business Intelligence Techniques. A Perspective from Accounting and Finance, Springer, 73-92. Retrieved from https://link.springer.com/ chapter/10.1007/978-3-540-24700-5_5

Xiao, J., Yang, H., and Chow C. W. (2004), The determinants and characteristics of voluntary Internetbased disclosures by listed Chinese companies, Journal of Accounting and Public Policy 23(3), 191-225. Retrieved from https://www.sciencedirect.com/science/article/pii/S0278425404000213

Yoon, H.,Zo, H., and Ciganek, A. P. (2011). Does XBRLadoption reduce information asymmetry? Journal of Business Research, 64(2), 157-163. Retrieved from https://scinapse.io/papers/2010370161 